\title{
STUDI LAMA PENGERINGAN IKAN SELAR (Selaroides sp) ASIN DIHUBUNGKAN DENGAN KADAR AIR DAN NILAI ORGANOLEPTIK
}

\author{
Adel Tuyu, Hens Onibala, Daisy M. Makapedua \\ Fakultas Perikanan dan Ilmu Kelautan, Universitas Sam Ratulangi, Manado, Sulawesi Utara.
}

\begin{abstract}
ABSTRAK
Penelitian ini bertujuan untuk mengetahui lama pengeringan ikan selar (Selaroides sp) asin dihubungkan dengan kadar air dan nilai organoleptiknya. Metode yang digunakan dalam penelitian ini merupakan metode eksperimen. Metode eksperimen merupakan bagian dari metode kuantitatif yang dilaksanakan di laboratorium. Dari hasil penelitian uji kadar air dapat dilihat hubungan kadar air dengan lama pengeringan menunjukan semakin lama pengeringan yang diberikan maka semakin rendah nilai kadar air produk ikan selar asin, nilai rata-rata kadar air yang tertinggi adalah $50,30 \%$ yaitu pada perlakuan dengan lama pengeringan 4 jam, sedangkan kadar air terendah adalah 20,91\% dengan perlakuan lama pengeringan $16 \mathrm{jam}$. Hal ini dapat dinyatakan bahwa lama pengeringan sangat mempengaruhi jumlah kadar air. Berdasarkan Standar Nasional Indonesia untuk kadar air bahwa produk ikan selar asin yang dikeringkan dengan alat pengering buatan (cabinet dryer) di atas 8 jam memiliki mutu yang baik. Pada uji organoleptik yaitu uji kenampakan, bau, rasa dan konsistensi nilai rata-rata tertinggi berada pada pengeringan di atas 12 jam, sehingga dapat dinyatakan bahwa ikan selar asin yang dikeringkan dengan cabinet dryer di atas 12 jam menghasilkan produk yang dapat diterima konsumen, sedangkan pengeringan di bawah 8 jam menghasilkan produk yang kurang diterima konsumen.
\end{abstract}

Kata kunci: Selar, ikan asin, kadar air, nilai organoleptik.

\section{PENDAHULUAN}

Ikan merupakan salah satu sumber protein hewani yang banyak dikonsumsi masyarakat, mudah didapat, dan harganya murah (Margono dkk., 2000). Namun hasil perikanan merupakan komoditas yang mudah mengalami proses kemunduran mutu dan pembusukan, dimana hal ini terjadi setelah ikan ditangkap. Dengan demikian perlu penanganan yang cepat, tepat dan benar untuk menjaga kualitasnya sebelum dipasarkan dan sampai ke tangan konsumen.

Proses pembusukan ikan dapat disebabkan terutama oleh aktivitas enzim yang terdapat di dalam tubuh ikan sendiri, aktivitas mikrooganisme, atau proses oksidasi pada lemak tubuh oleh oksigen dari udara. Kelemahan-kelemahan yang dimiliki oleh ikan telah dirasakan sangat menghambat usaha pemasaran hasil perikanan dan tidak jarang menimbulkan kerugian besar, terutama pada saat produksi ikan melimpah (Afrianto dan Liviawaty, 1989).

Proses pengolahan dan pengawetan ikan merupakan salah satu bagian penting dari mata rantai industri perikanan. Tanpa adanya kedua proses tersebut, peningkatan produksi ikan yang telah dicapai selama ini akan sia-sia, karena tidak semua produk perikanan dapat dimanfaatkan oleh konsumen dalam keadaan baik. Pengawetan ikan secara tradisional bertujuan untuk mengurangi kadar air dalam tubuh ikan, sehingga tidak memberikan kesempatan bagi bakteri untuk berkembang biak. Untuk mendapatkan hasil awetan yang bermutu tinggi diperlukan perlakuan yang baik selama proses pengawetan seperti : menjaga kebersihan bahan dan alat yang digunakan, menggunakan ikan yang masih segar, serta garam yang bersih. Ada bermacam-macam pengawetan ikan, antara lain dengan cara: penggaraman, pengeringan, pemindangan, perasapan, peragian dan pendinginan ikan (Margono $d k k$., 2000).

Penambahan garam menyebabkan protein ikan terdenaturasi sehingga daging ikan mengkerut dan air akan terperas keluar. Berkurangnya kadar air juga akan terjadi selama proses pengeringan, sehingga makin memperpanjang daya awet ikan asin (Astawan, 1997)

Salah satu produk awetan yang banyak terdapat di Indonesia adalah ikan asin. Dalam skala nasional, ikan asin merupakan salah satu produk perikanan yang mempunyai kedudukan penting, hal ini dapat dilihat bahwa hampir $65 \%$ produk perikanan masih diolah dan diawetkan dengan cara penggaraman (Afrianto dan Liviawaty, 1989). Pemerintah Indonesia telah 
menetapkan ikan asin sebagai salah satu dari sembilan bahan pokok masyarakat. Hal ini menunjukan bahwa ikan asin tidak hanya digemari oleh masyarakat ekonomi kelas bawah, tetapi juga kelas menengah dan atas. Daya tarik ikan asin ini terutama terletak pada cita-rasa, aroma dan teksturnya yang khas (Astawan, 1997).

Apabila ikan asin masih tetap dipertahankan sebagai bahan makanan pokok, maka pilihan teknologi haruslah pada industri pengeringan dengan mekanisasi penuh. Di daerah tropis, bila pengeringan dilakukan hanya pada sinar matahari, besar kemungkinan proses pembusukan akan terjadi. Untuk mencegah hal tersebut, maka sebaiknya dilakukan pengeringan dengan pengeringan buatan (cabinet dryer) sehinggga proses pengeringan dapat dipercepat (Berhimpon $d k k ., 1990)$.

Sehubungan dengan hal-hal tersebut, maka dirasa perlu untuk melakukan penelitian studi lama pengeringan ikan selar (Selaroides $\mathrm{sp)}$ asin dihubungkan dengan kadar air dan nilai organoleptik.

Penelitian ini bertujuan untuk mengetahui lama pengeringan ikan selar asin dihubungkan dengan kadar air dan nilai organoleptiknya.

\section{METODOLOGI PENELITIAN}

Metode yang digunakan dalam penelitian ini merupakan metode eksperimen. Metode eksperimen merupakan bagian dari metode kuantitatif yang dilaksanakan di laboratorium (Fatabura, 2012).

\section{Tata Laksana}

- Bahan ikan yang dilakukan penelitian di ambil dari tempat pelelangan ikan Tumumpa, yang kemudian dibawa ke Laboratorium Penanganan dan Pengolahan Hasil Perikanan FPIK Unsrat dengan cara meletakkan ikan dalam cool box yang diberi hancuran es.

- Setelah tiba di laboratorium, ikan tersebut kemudian dicuci dengan air bersih dan dibelah 2 sepanjang garis punggung sampai pada bagian perut (tapi jangan sampai terpisah), hal ini bertujuan agar daging ikan tidak terlalu tebal.

- Kemudian isi perut dan insang dikeluarkan, setelah itu ikan dicuci bersih agar semua kotoran yang masih melekat, terutama bagian rongga perut dan sisa-sisa pembuluh darah serta selaput yang ada dapat dibersihkan.

- Setelah itu ikan tersebut direndam dalam larutan air garam dengan konsentrasi 15\% dengan waktu perendaman 30 menit. Ikan kemudian diangkat dan ditiriskan sampai sisa-sisa air hasil rendaman sudah tidak meleleh lagi.

- Kemudian ikan dimasukkan kedalam pengering buatan (cabinet dryer) untuk dilakukan pengeringan. Suhu pengeringan berkisar $60-65^{\circ} \mathrm{C}$ dengan waktu perlakuan 4 jam, 8 jam 12 jam, dan 16 jam.

- Setelah pengeringan, ikan tersebut di angkat dan di dinginkan. Kemudian dilakukan pengujian Organoleptik dan Uji Kadar Air. Untuk lebih jelasnya dapat dilihat pada Gambar 2.

\section{Perlakuan Dan Rancangan Percobaan}

Berdasarkan hasil pra penelitian perlakuan dengan perendaman garam $15 \%$ lebih baik daripada perlakuan dengan kadar garam $5 \%$ dan $10 \%$, hal tersebut dapat dilihat dari hasil organoleptik produk ikan selar asin nilai rata-rata tertinggi berada pada perlakuan dengan perendaman garam $15 \%$, maka pada penelitian ini menggunakan larutan garam $15 \%$, dengan perlakuan sebagai berikut: ikan selar yang sudah dibelah dan direndam dalam larutan garam $15 \%$ selama 30 menit kemudian dilakukan pengeringan menggunakan alat pengering buatan dengan suhu $60-65^{\circ} \mathrm{C}$ selama:

- Pengeringan selama 4 jam

- Pengeringan selama 8 jam

- Pengeringan selama 12 jam

- Pengeringan selama 16 jam

\section{Analisis Kadar Air}

Penentuan kadar air yang dilakukan berdasarkan prosedur Badan Standarisasi Nasional (SNI-01-2354.2-2006) yaitu pengeringan dalam oven dengan prosedur sebagai berikut:

- Dikondisikan oven pada suhu $105^{\circ} \mathrm{C}$ hingga mencapai kondisi stabil.

- Dimasukan cawan kosong ke dalam oven selama 2 jam.

- Dipindahkan cawan kosong ke dalam desikator selama 30 menit sampai mencapai suhu ruang dan ditimbang bobot kosong (A).

- Ditimbang contoh yang telah dihaluskan sebanyak \pm 2 g ke dalam cawan (B). 
- Dimasukan cawan yang telah diisi dengan contoh ke dalam oven vakum pada suhu $105^{\circ} \mathrm{C}$ selama $24 \mathrm{jam}$.

- Dipindahkan cawan dengan menggunakan alat penjepit ke dalam desikator selama \pm 30 menit kemudian ditimbang $(\mathrm{C})$.

Ket.:

$$
\% \text { Kadar air }=\frac{B-C}{B-A} \times 100 \%
$$

$\mathrm{A}=$ berat cawan kosong dinyatakan dalam gram.

$\mathrm{B}=$ berat cawan + contoh awal, dinyatakan dalam gram.

$\mathrm{C}=$ berat cawan + contoh kering, dinyatakan dalam gram.

\section{Uji Organoleptik}

Pengujian sensori atau pengujian dengan indra atau dikenal juga dengan pengujian organoleptik sudah ada sejak manusia mulai menggunakan indranya untuk menilai kualitas dan keamanan suatu makanan dan minuman (Setyaningsih $d k k ., 2010$ ).

Terdapat tujuh jenis panel, yaitu panel pencicip perorangan, panel pencicip terbatas (3-5 orang ahli), panel terlatih (15-25 orang yang mempunyai kepekaan cukup baik dan diseleksi atau telah manjalani latihan-latihan), panel agak terlatih, panel tidak terlatih (terdiri dari 25 orang awam yang dapat dipilih berdasarkan jenis kelamin, suku bangsa, tingkat sosial dan pendidikan), panel kosumen (terdiri dari 30-100 orang yang tergantung pada target pemasaran suatu komoditas) dan panel anakanak (umumnya anak-anak berusia 3-10 tahun) (Setyaningsih $d k k$., 2010).

Pengujian organoleptik dalam penelitian ini dilakukan uji kenampakan, bau, cita rasa dan konsistensi, dengan panelis berjumlah 30 orang. Pengujian ini dilakukan dengan cara menyajikan sampel dan diberikan score sheet pada panelis, kemudian panelis diminta untuk menentukan nilai dari setiap bahan uji.

Sebelum panelis menilai atau mencontreng pada lembar score sheet, terlebih dahulu dijelaskan tentang cara-cara penilaian terhadap kenampakan, bau, rasa dan konsistensi. Sampel diberi nomor kode dan disajikan secara acak.

\section{HASIL DAN PEMBAHASAN}

\section{Analisa Kadar Air}

Hasil analisa kadar air ikan selar asin dapat dilihat pada Tabel 1.

Berdasarkan data Tabel 1 tersebut dapat dilihat bahwa nilai rata-rata kadar air yang tertinggi adalah $50,30 \%$ yaitu pada perlakuan dengan lama pengeringan 4 jam, sedangkan kadar air terendah adalah 20,91\% dengan perlakuan lama pengeringan $16 \mathrm{jam}$.

Hubungan nilai kadar air dengan lama pengeringan dapat dilihat pada Gambar 1 .

Tabel 1. Data hasil analisis kadar air ikan selar (Selaroides sp) asin.

\begin{tabular}{cccc}
\hline \multirow{2}{*}{ Lama Pengeringan } & \multicolumn{2}{c}{ Kadar Air (\%) } & \multirow{2}{*}{ Rata-rata(\%) } \\
\cline { 2 - 3 } & $\mathbf{1}$ & $\mathbf{2}$ & \\
\hline 4 Jam & 49.85 & 50.74 & 50.30 \\
8 Jam & 34.99 & 35.30 & 35.15 \\
12 Jam & 27.58 & 26.15 & 26.87 \\
16 Jam & 20.33 & 21.48 & 20.91 \\
\hline
\end{tabular}

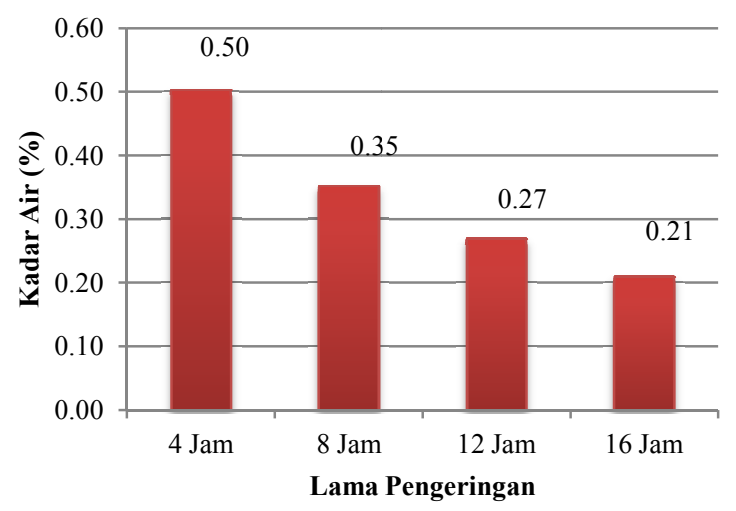

Gambar 1. Hubungan kadar air ikan selar asin dengan lama waktu pengeringan.

Berdasarkan Gambar 1 dapat dilihat bahwa hubungan kadar air dengan lama pengeringan menunjukkan bahwa semakin lama waktu pengeringan yang diberikan maka semakin rendah nilai kadar air produk ikan selar asin tersebut, atau juga dapat dinyatakan bahwa semakin lama waktu pengeringan maka semakin banyak kandungan air yang keluar dari produk tersebut. Hal ini dapat dinyatakan bahwa lama pengeringan sangat mempengaruhi jumlah kadar air dalam produk.

Menurut Harikedua $d k k$. (1991), pengeringan ikan dapat mengeluarkan atau menghilangkan sebagian air dari suatu bahan dengan cara menguapkan air dalam bahan tersebut dengan menggunakan energi panas. Lebih lanjut menurut Moeljanto (1982) pengeringan didasari atas terjadinya penguapan air karena adanya perbedaan kandungan uap air antara udara dengan produk yang dikeringkan. Kandungan uap air udara lebih rendah dari kandungan uap air produk sehingga dapat terjadi penguapan. Makin besar perbedaan tersebut, makin banyak kandungan uap air produk yang dikeringkan dapat menguap.

Faktor yang dapat mengakibatkan produk kehilangan berat dalam hal ini terjadi pengurangan kadar air selama proses pengeringan adalah lama pengeringan, suhu 
pengeringan, luas permukaan produk, jenis dan ukuran ikan serta jumlah garam yang diberikan (Earle, 1979 dalam Ruus, 2009).

Dari hasil penelitian Ruus (2009) dan Lukas (2011) juga menyatakan bahwa semakin lama waktu pengeringan yang dilakukan terhadap produk ikan asin maka akan semakin rendah nilai kadar air dari produk tersebut.

Menurut Badan Standar Nasional (1992), kadar air ikan asin berdasarkan Standar Nasional Indonesia adalah 40\%. Dengan demikian produk ikan selar asin yang mendapat perlakuan dengan lama pengeringan 8 jam, 12 jam serta 16 jam berada pada kisaran mutu yang baik. Menurut Soeseno (1985), kadar air yang baik untuk semua jenis ikan asin yaitu 30\%. Lebih lanjut Moeljanto (1992) menyatakan bahwa bila kandungan air dalam produk bisa di turunkan sampai 30\%, maka aktivitas bakteri akan terhambat.

\section{Uji Organoleptik}

\section{Kenampakan}

Hasil uji organoleptik kenampakan ikan selar asin dapat dilihat pada Tabel 2.

Tabel 2. Data hasil pengamatan nilai uji organoleptik kenampakan ikan selar (Selaroides sp) asin.

\begin{tabular}{ccccc}
\hline \multirow{2}{*}{ Lama Pengeringan } & \multicolumn{2}{c}{$\begin{array}{c}\text { Nilai Uji Organoleptik } \\
\text { Kenampakan }\end{array}$} & Total & $\begin{array}{c}\text { Rata- } \\
\text { rata }\end{array}$ \\
\cline { 2 - 3 } & $\mathbf{1}$ & $\mathbf{2}$ & & \\
\hline 4 Jam & 5.73 & 5.93 & 11.67 & $\mathbf{5 . 8 3}$ \\
8 Jam & 6.53 & 6.73 & 13.27 & $\mathbf{6 . 6 3}$ \\
12 Jam & 7.27 & 7.47 & 14.73 & $\mathbf{7 . 3 7}$ \\
16 Jam & 8.13 & 8.40 & 16.53 & $\mathbf{8 . 2 7}$ \\
\hline
\end{tabular}

Berdasarkan data Tabel 2 tersebut dapat dilihat bahwa nilai rata-rata organoleptik kenampakan yang tertinggi adalah 8,27 yaitu pada perlakuan dengan lama pengeringan 16 jam, sedangkan nilai organoleptik kenampakan terendah adalah 5,83 dengan perlakuan lama pengeringan 4 jam.

Hubungan jumlah kadar air terhadap nilai organoleptik kenampakan ikan selar asin dan lama waktu pengeringan dapat dilihat pada Gambar 2.

Berdasarkan Gambar 2 dapat dilihat bahwa semakin rendah jumlah kadar air ikan selar asin dan semakin lama waktu pengeringan yang diberikan maka nilai organoleptik untuk kenampakan semakin meningkat. Hal ini dapat dinyatakan bahwa lama pengeringan dan jumlah kadar air dapat mempengaruhi tingkat kesukaan panelis/konsumen terhadap ikan selar asin. Berdasarkan hasil diatas dapat dinyatakan bahwa semakin rendah jumlah kadar air dari produk ikan selar asin maka tingkat kesukaan kenampakan produk tersebut semakin baik.

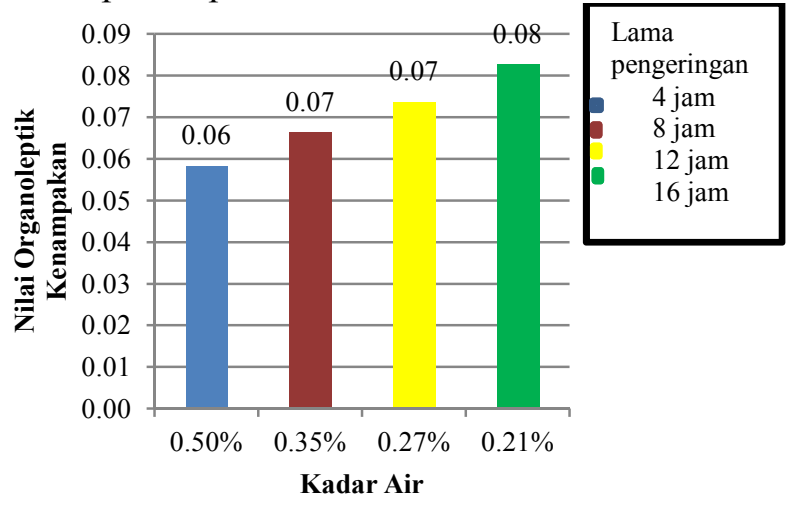

Gambar 2. Hubungan jumlah kadar air terhadap nilai organoleptik kenampakan ikan selar asin dan lama waktu pengeringan.

Winarno (1980) menyatakan bahwa kadar air merupakan komponen penting dalam bahan pangan karena dapat mempengaruhi nilai kenampakan pada produk. Selanjutnya Harikedua $d k k$. (1991) menambahkan bahwa pengeringan merupakan suatu metode untuk mengeluarkan atau menghilangkan sebagian air dari suatu bahan dengan cara menguapkan air dalam bahan tersebut dengan menggunakan energi panas. Jadi dengan kata lain bahwa semakin lama penggunaan energi panas atau semakin lama waktu pengeringan maka jumlah kadar air akan semakin menurun sehingga daging ikan akan lebih utuh. Tinggi rendahnya nilai kenampakan dari produk ikan asin tersebut sangat dipengaruhi oleh kandungan air pada produk tersebut.

Menurut Badan Standar Nasional (1992), nilai organoleptik berdasarkan Standar Nasional Indonesia (SNI) adalah 6,5. Dengan demikian produk yang mendapat perlakuan dengan lama pengeringan 8 jam, 12 jam serta 16 jam berada pada kisaran mutu yang baik.

\section{Bau}

Hasil uji organoleptik bau ikan selar asin dapat dilihat pada Tabel 3 .

Tabel 3. Data hasil pengamatan nilai uji organoleptik bau ikan selar (Selaroides sp) asin.

\begin{tabular}{|c|c|c|c|c|}
\hline \multirow{2}{*}{$\begin{array}{c}\text { Lama } \\
\text { Pengeringan }\end{array}$} & \multicolumn{2}{|c|}{$\begin{array}{c}\text { Nilai Uji } \\
\text { Organoleptik Bau }\end{array}$} & \multirow[t]{2}{*}{ Total } & \multirow{2}{*}{$\begin{array}{c}\text { Rata- } \\
\text { rata }\end{array}$} \\
\hline & 1 & 2 & & \\
\hline 4 Jam & 5.40 & 5.33 & 10.73 & 5.37 \\
\hline $8 \mathrm{Jam}$ & 5.73 & 6.07 & 11.80 & 5.90 \\
\hline $12 \mathrm{Jam}$ & 7.07 & 7.40 & 14.47 & 7.23 \\
\hline $16 \mathrm{Jam}$ & 8.20 & 8.27 & 16.47 & 8.23 \\
\hline
\end{tabular}


Berdasarkan data Tabel 3 dapat dilihat bahwa nilai rata-rata organoleptik bau yang tertinggi adalah 8,23 yaitu pada perlakuan dengan lama pengeringan 16 jam, sedangkan kadar air nilai organoleptik bau terendah adalah 5,37 dengan perlakuan lama pengeringan 4 jam.

Hubungan jumlah kadar air terhadap nilai organoleptik bau ikan selar asin dan lama waktu pengeringan dapat dilihat pada Gambar 3.

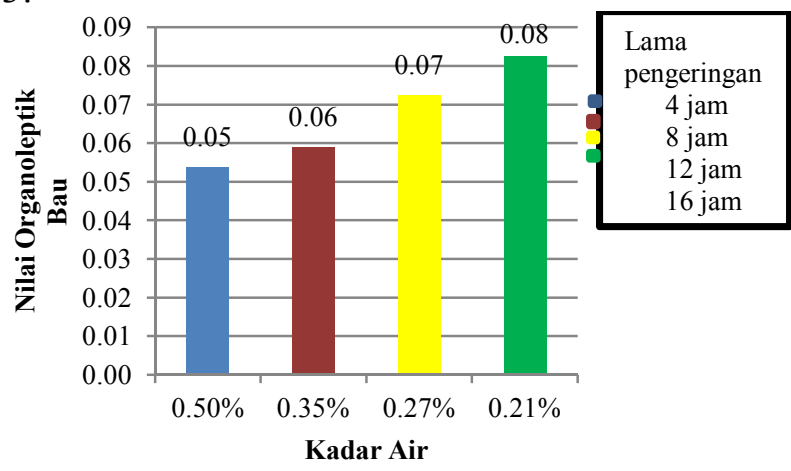

Gambar 3. Hubungan jumlah kadar air terhadap nilai organoleptik bau ikan selar asin dan lama waktu pengeringan.

Berdasarkan Gambar 3 dapat dilihat bahwa semakin rendah jumlah kadar air ikan selar asin dan semakin lama waktu pengeringan yang diberikan maka nilai organoleptik untuk bau semakin tinggi. Semakin tingginya nilai bau disebabkan oleh semakin kurangnya kadar air dalam daging ikan akibat pengeringan, sehingga bau asli daripada daging ikan (bau anyir) menghilang dan bau yang ditimbulkan akibat garam lebih terasa. Menurut Astawan (1997) daya tarik ikan asin terletak pada aromanya yang khas, selain rasa dan tekstur. Hal ini dapat dinyatakan bahwa lama pengeringan dan jumlah kadar air dapat mempengaruhi tingkat kesukaan panelis/konsumen terhadap ikan selar asin.

Seperti halnya pada uji kenampakan, berdasarkan hasil diatas dapat dinyatakan bahwa semakin rendah jumlah kadar air dari produk ikan selar asin maka nilai organoleptik bau produk tersebut semakin baik.

Berdasarkan SNI (1992) nilai organoleptik yang baik adalah 6,5. Dengan demikian produk yang mendapat perlakuan dengan lama pengeringan 12 jam serta 16 jam berada pada kisaran mutu yang baik.

\section{Rasa}

Hasil uji organoleptik rasa ikan selar (Selaroides sp) asin dapat dilihat pada Tabel 4.
Tabel 4. Data hasil pengamatan nilai uji organoleptik rasa ikan selar (Selaroides sp) asin.

\begin{tabular}{ccccc}
\hline \multirow{2}{*}{$\begin{array}{c}\text { Lama } \\
\text { Pengeringan }\end{array}$} & \multicolumn{2}{c}{$\begin{array}{c}\text { Nilai Uji } \\
\text { Organoleptik Rasa }\end{array}$} & Total & $\begin{array}{c}\text { Rata- } \\
\text { rata }\end{array}$ \\
\cline { 2 - 3 } & $\mathbf{1}$ & $\mathbf{2}$ & & \\
\hline 4 Jam & 4.07 & 4.00 & 8.07 & $\mathbf{4 . 0 3}$ \\
8 Jam & 5.27 & 5.60 & 10.87 & $\mathbf{5 . 4 3}$ \\
12 Jam & 6.80 & 7.33 & 14.13 & $\mathbf{7 . 0 7}$ \\
16 Jam & 8.07 & 8.53 & 16.60 & $\mathbf{8 . 3 0}$ \\
\hline
\end{tabular}

Berdasarkan data Tabel 4 dapat dilihat bahwa nilai rata-rata organoleptik rasa yang tertinggi adalah 8,30 yaitu pada perlakuan dengan lama pengeringan $16 \mathrm{jam}$, sedangkan nilai organoleptik rasa terendah adalah 4,03 dengan perlakuan lama pengeringan 4 jam.

Hubungan jumlah kadar air terhadap nilai organoleptik rasa ikan selar asin dan lama waktu pengeringan dapat dilihat pada Gambar 4.

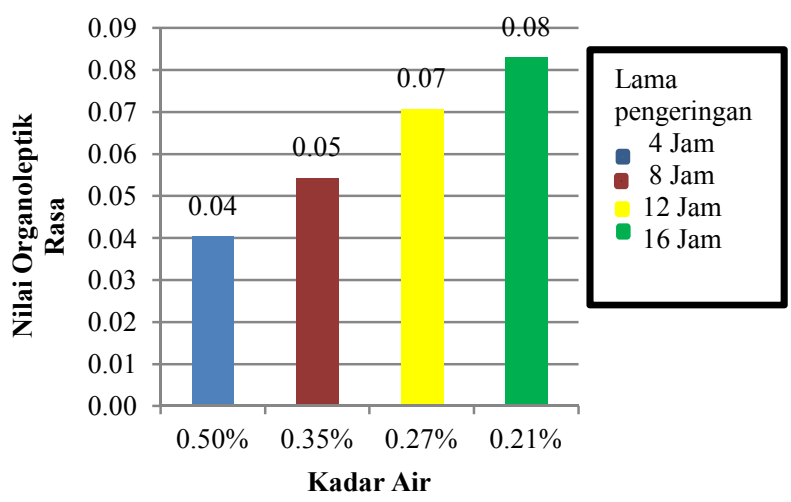

Gambar 4. Hubungan jumlah kadar air terhadap nilai organoleptik rasa ikan selar asin dan lama waktu pengeringan.

Pada Gambar 4 dapat dilihat bahwa semakin rendah jumlah kadar air ikan selar asin dan semakin lama waktu pengeringan yang diberikan maka nilai organoleptik untuk rasa semakin meningkat. Hal ini dapat dinyatakan bahwa lama pengeringan dan jumlah kadar air dapat mempengaruhi tingkat kesukaan panelis/konsumen terhadap ikan selar asin. Seperti halnya pada uji kenampakan, berdasarkan hasil diatas dapat dinyatakan bahwa semakin rendah jumlah kadar air dari produk ikan selar asin maka nilai organoleptik rasa produk tersebut semakin baik. Menurut Peranginangin (1983), garam dapat merangsang cita rasa dan menambah rasa enak pada produk. Selanjutnya menurut Astawan (1997) daya tarik ikan asin salah satu terletak pada rasa yang khas. Berdasarkan Standar Nasional Indonesia (1992) nilai organoleptik yang baik adalah 6,5. Dengan demikian produk yang mendapat 
perlakuan dengan lama pengeringan 12 jam serta 16 jam berada pada kisaran mutu yang baik.

\section{Konsistensi}

Hasil uji organoleptik konsistensi ikan selar asin dapat dilihat pada Tabel 5.

Tabel 5. Data hasil pengamatan nilai uji organoleptik konsistensi ikan selar (Selaroides sp) asin.

\begin{tabular}{ccccc}
\hline \multirow{2}{*}{$\begin{array}{c}\text { Lama } \\
\text { Pengeringan }\end{array}$} & \multicolumn{2}{c}{$\begin{array}{c}\text { Nilai Uji } \\
\text { Organoleptik Konsistensi }\end{array}$} & Total & $\begin{array}{c}\text { Rata- } \\
\text { rata }\end{array}$ \\
\cline { 2 - 3 } & $\mathbf{1}$ & $\mathbf{2}$ & & \\
\hline 4 Jam & 5.60 & 5.80 & 11.40 & $\mathbf{5 . 7 0}$ \\
8 Jam & 6.07 & 6.47 & 12.53 & $\mathbf{6 . 2 7}$ \\
12 Jam & 7.07 & 6.87 & 13.93 & $\mathbf{6 . 9 7}$ \\
16 Jam & 7.67 & 8.20 & 15.87 & $\mathbf{7 . 9 3}$ \\
\hline
\end{tabular}

Berdasarkan data Tabel 5 tersebut dapat dilihat bahwa nilai rata-rata organoleptik konsistensi yang tertinggi adalah 7,93 yaitu pada perlakuan dengan lama pengeringan 16 jam, sedangkan nilai organoleptik konsistensi terendah adalah 5,70 dengan perlakuan lama pengeringan $4 \mathrm{jam}$.

Hubungan jumlah kadar air terhadap nilai organoleptik konsistensi ikan selar asin dan lama waktu pengeringan dapat dilihat pada Gambar 5.

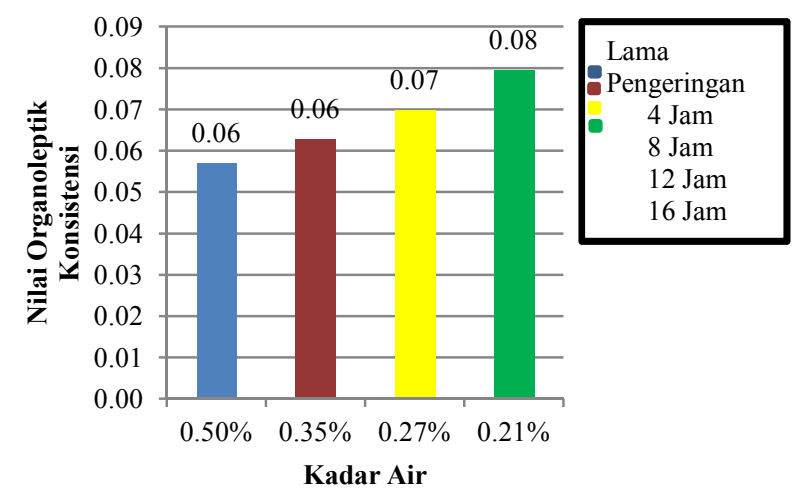

Gambar 5. Hubungan jumlah kadar air terhadap nilai organoleptik konsistensi ikan selar asin dan lama waktu pengeringan.

Pada Gambar 5 dapat dilihat bahwa semakin rendah jumlah kadar air ikan selar asin dan semakin lama waktu pengeringan yang diberikan maka nilai organoleptik untuk konsistensi semakin meningkat. Hal ini dapat dinyatakan bahwa lama pengeringan dan jumlah kadar air dapat mempengaruhi tingkat kesukaan panelis/konsumen terhadap ikan selar asin. Berdasarkan hasil diatas dapat dinyatakan bahwa semakin rendah jumlah kadar air dari produk ikan selar asin maka nilai organoleptik konsistensi produk tersebut semakin baik.
Dengan kata lain bahwa semakin rendahnya jumlah kadar air maka daging ikan akan semakin kompak dan keras.

Hasil penelitian Ruus (2009) dan Lukas (2011) menyatakan bahwa pemberian konsentrasi garam yang semakin tinggi dan semakin lama waktu pengeringan akan lebih besar menurunkan kadar air dari dalam tubuh ikan. Hal ini disebabkan karena selama proses pengeringan, ikan menerima panas sehingga kadar air dalam bahan menguap. Dengan berkurangnya jumlah kadar air dalam produk ikan asin tersebut maka akan membuat konsistensi dari produk ikan asin lebih baik.

Berdasarkan Standar Nasional Indonesia (1992) nilai organoleptik yang baik adalah 6,5. Dengan demikian produk yang mendapat perlakuan dengan lama pengeringan 12 jam serta 16 jam berada pada kisaran mutu yang baik.

\section{KESIMPULAN}

Berdasarkan hasil penelitian ini, maka dapat disimpulkan bahwa:

- Ikan asin yang dikeringkan melebihi 12 jam pemanasan pada cabinet dryer menghasilkan produk yang dapat diterima oleh konsumen, sedangkan pengeringan di bawah 8 jam menghasilkan produk yang kurang diterima oleh konsumen.

- Berdasarkan Standar Nasional Indonesia (SNI) untuk kadar air bahwa produk ikan selar asin yang dikeringkan dengan cabinet dryer di atas 8 jam memiliki mutu yang baik.

Perlu adanya uji lanjut tentang masa simpan serta perlu penggunaan pengemasan yang higienis.

\section{DAFTAR PUSTAKA}

Afrianto E. dan E. Liviawati. 1989. Pengawetan dan Pengolahan Ikan. Kanisius, Yogyakarta.

Astawan M. 1997. Mengenal Makanan Tradisional Produk Olahan Ikan. isjd.pdii.lipi.go.id/admin/jurnal/ 83975862.pdf. Manado, 15 Februari 2012, Pukul 14.015 Wita.

Berhimpon, S, Souness R.A., Buckle K.A. and Edwards R.A. 1990. The Effect on Brine Concentration on the Salting and Drying of Yellowtail (Trachurus meccullochi). Indo-Pacific Fisheries Comkision (IPFC), FAO-US. FAO Fisheries report No.401 Supplement, pp 153-159.

Badan Standar Nasional. 1992. Standar Nasional Indonesia (SNI) Ikan Asin Kering. Kumpulan Standar Metode Pengujian Mutu Hasil Perikanan. Jakarta. 
Badan Standar Nasional. 2009. Standar Nasional Indonesia (SNI) Ikan Asin Kering. Spesifikasi. Jakarta.

Badan Standar Nasional. 2006. Standar Nasional Indonesia (SNI) Cara Uji Kimia. Penentuan kadar air pada produk perikanan. Jakarta

Buckle K.A, R.A. Edwards, F.H. Fleet, M. Wooton. 1987. Ilmu Pangan. Penerbit UI-Press. Jakarta

Fatabura H. 2012. Metode Penelitian Eksperimen. sospol.untag-smd.ac.id/?p=347. Manado, 5 Juni 2012, Pukul 14.015 Wita.

Harikedua, J.W., Kaseger B., Sanger G., Setyaningsih L., Singal A., Pandey E., dan Dolonseda S,. 1991. Bahan Ajar Untuk Mata Kuliah Pengantar Pengolahan Hasil Perikanan. Fakultas Perikanan Universitas Sam Ratulangi. Manado.

Lukas R. J. 2011. Kajian Mutu Ikan Kakap Merah (Lutjanus sp) Yang Di Olah Dengan Pemberian Konsentrasi Larutan Garam Dan Lama Pengeringan Yang Berbeda. Skripsi. Fakultas Perikanan dan Ilmu Kelautan, Universitas Sam Ratulangi. Manado.

Margono,T, Suryati,D, Hartinah,S. 2000. Ikan Asin Cara Kombinasi Penggaraman Dan Peragian (Ikan Peda) www.warintek.ristek.go.id/pangan_kesehatan/pangan/ piwp/ikan_asin_kombinasi.pdf. Manado, 24 Oktober 2011, Pukul 17.20 Wita
Moeljanto, R. 1982. Penggaraman dan Pengeringan Ikan. Penerbit PT. Penebar Swadaya. Jakarta.

Moeljanto, R. 1992. Pengawetan dan Pengolahan Hasil Perikanan. PT. Penebar Swadaya. Jakarta.

Peranginangin, R.. 1983. Penelitian Dendeng Tawes (Puntius javanicus) Dalam Berbagai Bentuk Olahan. Laporan Penelitian Teknologi Perikanan. Balai Pengembangan Pertanian. Departemen Pertanian. Jakarta.

Ruus. O.V. 2009. Pengaruh Konsentrasi Larutan Garam Dan Lama Pengeringan Terhadap Mutu Ikan Layang (Decapterus sp) Asin Dengan Kadar Garam Rendah. Skripsi. Fakultas Perikanan dan Ilmu Kelautan Universitas Sam Ratulangi. Manado.

Setyaningsih D; Anton A; Maya. P. S. 2010. Analisis Sensori untuk industri pangan. IPB Press. Bogor.

Soeseno. 1985. Teknik Penangkapan dan Teknologi Ikan. Yasaguna. Jakarta.

Soekarto S. 1991. Penilaian Organoleptik Untuk Industri Pangan dan Hasil Pertanian. IPB. Bogor.

Winarno F.G, S. Fardiaz; dan D. Fardiaz. 1980. Pengantar Teknologi Pangan. PT. Gramedia. Jakarta. 